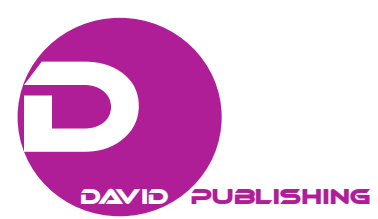

\title{
Entrepreneurial Innovative Strategies for Diaspora Entrepreneurship Growth Among Kenyan Immigrants
}

\author{
Erastus Thoronjo Muriuki \\ Mount Kenya University, Thika, Kenya
}

\begin{abstract}
Globally entrepreneurial strategies are becoming more important for both new as well as established enterprises. Entrepreneurs are realizing that in response to an increasingly complex world, having an "entrepreneurial spirit" isn't enough: a strong commitment to use of unique strategies is a critical factor for success for entrepreneurs. Entrepreneurship is one possibility for migrants to contribute to development, both in their countries of origin and in their countries of destination as they generate jobs and stimulate the local economy. Entrepreneurship is higher among qualified migrants, while low-skilled migrant entrepreneurs are more likely to concentrate on local ethnic business. Migrants make use of capital and know-how acquired by return migrants during the migration process and often pioneer new business areas, transnational firms, in expansion business enterprises located in the country of origin that enter markets abroad, expatriate communities being the main target group for their products and business associates and identified business partners. This study sought to find the link between entrepreneurship strategies and entrepreneurial growth by studying the entrepreneurial strategies for enhancing entrepreneurship using a case of Kenyan Diaspora. The objective was to evaluate influence of entrepreneurial strategies on the growth of Diaspora entrepreneurship among Kenyans living abroad. The study adopted an explanatory research design on 125 Kenyan Diaspora entrepreneurs from whom primary data were collected using a questionnaire which was then analysed using descriptive and inferential statistics. The study found that entrepreneurship strategies such as innovation, networking, proactiveness, and strategic partnerships have an $87.6 \%$ impetus to improve entrepreneurial growth among the Kenyan Diaspora entrepreneurs and concluded that Diaspora entrepreneurial strategies have the ability to enhance entrepreneurial growth among migrants. It recommends Kenyan embassies to provide entrepreneurial training to enhance entrepreneurship knowledge among the Diaspora communities globally and hence promote Diaspora entrepreneurship.
\end{abstract}

Keywords: entrepreneurship, Diaspora entrepreneurship, entrepreneurial strategies, innovative strategies, networking, strategic partnership

\section{Background of the Study}

In the new competitive landscape, entrepreneurial strategies are becoming more and more important for both new as well as established enterprises. Entrepreneurship is becoming more and more visible as a legitimate means for job creation and economic recovery (Arthur, Hisrich, \& Cabrera, 2012). People are also

Erastus Thoronjo Muriuki, Dr., Ph.D. in entrepreneurship, Mount Kenya University, Thika, Kenya.

Correspondence concerning this article should be addressed to Erastus Thoronjo Muriuki, Department of Management, School of Business and Economics, Mount Kenya University, P.O. Box 342, Thika 01000, Kenya. 
realizing that in response to an increasingly complex world, having an "entrepreneurial spirit" isn't enough: a strong commitment to use of unique strategies is a critical factor for success for entrepreneurs as well as for countries at all stages of economic development (Arthur et al., 2012). Entrepreneurship is one possibility for migrants to contribute to development, both in their countries of origin and in their countries of destination as they generate jobs and stimulate the local economy. Migrants are most likely to become successful entrepreneurs if business skills have already been accumulated before migration and when the receiving society provides a business-enabling environment. Studies on this subject show that the level of entrepreneurship is higher among qualified migrants, while low-skilled migrant entrepreneurs are more likely to concentrate on ethnic business (Portes \& Yiu, 2013). Based on these determinants, two major types of migrant entrepreneurs can be distinguished: Those with modest educational background and resources; and those with suitable qualifications. A more detailed typology of migrant enterprises (Portes \& Yiu, 2013) is mainly based on the level and quality of interaction of migrant entrepreneurs between their countries of origin and destination. Circuit enterprises are transnational firms that deliver money and goods between both countries. Cultural enterprises offer cultural products that are customary in the country of origin and demanded by migrants in the country of destination (newspapers, books, music, etc.). Ethnic enterprises offer products both to an expatriate and an interested mainstream clientele (mainly restaurants, stores for food or clothing). Migrant return enterprises make use of capital and know-how acquired by return migrants during the migration process and often pioneer new business areas and transnational firms in expansion are enterprises located in the country of origin that enter markets abroad, expatriate communities being the main target group for their products (Portes \& Yiu, 2013). Study on transnational strategies among small-scale ICT entrepreneurs shows that younger and less advantaged entrepreneurs highly benefitted from international mobility in terms of their return on investment in Ghana (IMI, 2011). Based on a survey of internet cafés in remote and poor areas of Ghana, it points out that working abroad and international networking enable entrepreneurs to acquire knowledge, hardware, software, and capital needed to start an internet café. Furthermore, even businesses of non-migrants may be sustained by the inflow of ICT skills and resources through transnational networks. The survey illustrated that the migration experience does not only have a positive impact if the migrants have worked in the ICT sector abroad, but also if they have worked in any other sector (IMI, 2011).

\section{Statement of the Problem}

Owing to a wave of migrations from one country to another, mobility of skills and expertise has been experienced in the last three decades. One majorly lost skill due to mobility is that of entrepreneurship. However, adoption of Diaspora entrepreneurship has the capacity to develop this skill. Diaspora entrepreneurship has the potential to contribute to the economic growth in both the country of origin and the host countries (Newland \& Tanaka, 2010). Migrants have been recognised as more entrepreneurial than the domestic population due to their wider experiences scope (OECD, 2010). Diaspora entrepreneurship advances business development, job creation, and innovation. The investments in entrepreneurial activities made by Diaspora can directly and indirectly create jobs and facilitate competition that can lead to innovation, more businesses, and increased job opportunities. Economic growth includes change and as such, entrepreneurs are great agents to advocate the change. Secondly, Diaspora Direct Investment (DDI) creates economic, social, and political capital through global networks. Since developing countries have often been in an isolated position from global flows of trade, finances, and knowledge, Diaspora entrepreneurs can provide networks in both their 
countries of origin and destination. Also Diaspora entrepreneurship taps into social capital through cultural and linguistic understanding. The knowledge of local (business) culture, norms and values, and language expertise creates social capital by virtue of cultural and linguistic understanding. Research has shown that a strong positive correlation exists between higher level of entrepreneurship and higher level of economic growth (Acs, 2006). However, Diaspora entrepreneurs have not had a smooth sail making their entrepreneurial ventures. The migrant entrepreneurs face some setbacks such as lack funding, face stiff competition, high cash burn rate, lack of legitimacy, management team formation, identifying an appropriate market segment, protecting intellectual property, operational issues, and legal/regulatory issues among other challenges (Chu et al., 2007). This shows that although the Diaspora entrepreneurs may have right managerial skills, education, experience and training, psychological traits, social networks, and environmental conditions (Benzing, Chu, \& Kara, 2009; Zimmerman \& Jiang, 2009), to growth Diaspora entrepreneurship may be difficult since the above problems are quite difficult to address and may threaten the start-up and growth of a new business. Despite this, previous studies done have not focused on entrepreneurial strategies for enhancing entrepreneurship for Kenyan Diaspora. This study therefore sought to fill this gap in knowledge by studying the entrepreneurial strategies for enhancing entrepreneurship among the Kenyan Diaspora entrepreneurs.

\section{Research Objectives}

This study sought to evaluate influence of entrepreneurial strategies on the growth of Diaspora entrepreneurship among Kenyan immigrants. The specific objectives are:

i. To establish how innovativeness affects the growth of Kenyan Diaspora investments;

ii. To determine how networking influences the growth of Diaspora entrepreneurship;

iii. To establish the influence of proactiveness on the growth of Diaspora entrepreneurship;

iv. To explore the effect of strategic partnership on the growth of Diaspora entrepreneurship.

\section{The Scope of the Study}

The research will study the entrepreneurial strategies that influence Diaspora entrepreneurship. The research will collect data on the entrepreneurial strategies being pursued by the Kenyan immigrant entrepreneurs in Diaspora entrepreneurship. This is expected to cover data from the Kenyans in Diaspora community who are engaged in any form of entrepreneurial activities.

\section{Literature Review}

\section{Theoretical Review}

There are many concepts and rational thinking from some early scholars who explain the natural phenomena. This study will be guided by theories on entrepreneurship.

The theory of transnational entrepreneurship. The theory of transnational entrepreneurship is based on Portes's (1995) view of international entrepreneurship. The theory opens a new frontier to develop insights on the formation and impact of glocalized networks across geographic and ethnic boundaries. To illuminate the role of glocalized networks in transnational entrepreneurship, knowledge of how entrepreneurs rely on glocalized networks to engage in transnational entrepreneurship is of essence. As a relatively new research area, most existing transnational entrepreneurship (TE) studies have taken it as a priority to legitimatize the topic as theoretically interesting and practically significant (Portes et al., 2002). More recently, studies have begun to examine its mechanisms. Transnational entrepreneurship is shaped by a confluence of social forces at multiple 
levels in the dual institutional context in both the sending and receiving countries. Social networks have been underlying theorizing on immigrant transnationalism. Various definitions of transnationalism involve networks. Border-crossing networks are theorized as the foundation of the transnational social field and the primary means of mobilizing resources for transnational practices (Vertovec, 2003). Thus, Portes, Guranizo, and Landolt (1999) argue that understanding how networks enable immigrants to combine resources in the host and home countries is the key to transnationalism research.

Schultz's theory on entrepreneurship. In Schultz's formulation, entrepreneurship is the ability to adjust, or reallocate resources, in response to changing circumstances. As such, entrepreneurship is an aspect of all human behaviour, not a unique function performed by a class of specialists. "No matter what part of the economy is being investigated, we observe that people are consciously reallocating their resources in response to changes in economic conditions" (Schultz, 1979, p. 2). Businessmen, farmers, housewives, students, and even university presidents, deans, and research directors make Schultz's (1979) list of entrepreneurs (Holmes \& Schmitz, 2001). Somewhat paradoxically, the degree to which entrepreneurship is manifested in a society is itself determined by supply and demand. The demand for entrepreneurial services is given by the expected gains from adjusting one's resources in the face of the disequilibrium, itself a function of some characteristics of that disequilibrium. The supply of entrepreneurial capacities is given by agents' abilities to perceive and exploit opportunities. Like any economic goods, entrepreneurship is valuable and scarce (Schultz, 1979, p. 6). Knight (1942) and Kirzner (1973) treat entrepreneurship as "extra-economic", meaning that it is the driving force behind the pricing process, but is not itself traded and priced on the market. Schultz (1979) insists that entrepreneurial ability, like other services available for hire, is a resource with a market price and quantity, though he did not develop this insight into a fully specified theory of the supply of and demand for entrepreneurship.

The opportunity identification approach. In a rapidly changing world, organizations need to continually identify new opportunities beyond existing competencies if they are to survive and prosper (McGrath, Tsai, Venkataraman, \& MacMillan, 1996). The identification of opportunities has been recognized as one of the most important abilities of successful entrepreneurs (Ardichvili, Cardozo, \& Ray, 2003) and consequently has become an important element of the scholarly study of entrepreneurship. Gaglio and Katz (2001) contend that understanding the opportunity identification process represented one of the core intellectual questions for the domain of entrepreneurship. As such, an opportunity does not exist until an entrepreneur "creates" it. In a nutshell, entrepreneurial opportunities occur when "new goods, services, raw materials, markets, and organizing methods can be introduced through the formation of new means, ends, or means-ends relationships" (Eckhardt \& Shane, 2003, p. 333). An individual's ability to recognize an opportunity is regarded in recent research as a crucial first step in launching an entrepreneurial venture (Baron, 2006). Also opportunity identification is a key element in the historical development of entrepreneurial thought (Murphy, Liao, \& Welsch, 2006).

\section{Kenyan Entrepreneurial Scene}

Entrepreneuship is fast growing in Kenya. This is evident as there are many business people who operate many different enterprises. A business manager, for instance, who astutely guides, organizes, directs, or co-ordinates the operations of a business venture, by making decisions on the use of productive factors, or the nature, quality, and style of products or services to be produced and on marketing and time factors, is, indeed, 
an entrepreneur. In so doing, the manager may outrightly innovate or as is more commonly the case, exercise creative imitation, often referred to as adaptation (Njeru, 1996). The question of what factors lead individuals to become entrepreneurs is an old one. It is also common knowledge that although the propensity to entrepreneurship varies from one society to another, a universal constant is that no matter how many entrepreneurs emerge, most do not succeed in creating lasting organizations. In Kenya, self-employment invokes an image of entrepreneurship. Approximately 500,000 graduates from various tertiary academic institutions enter the job market annually (Government of Kenya, 2008). However, due to low economic growth, among other factors, and demand for experience by potential employees, a majority of youth remains unemployed (Government of Kenya, 2008). It is therefore important to work hard to understand how and why entrepreneurs succeed, as this is key in ensuring employment. The Government of Kenya recognizes the significant contribution of Kenyans living abroad to its National Development Agenda. This is further exemplified in Vision 2030 which envisages engaging the Diaspora in nation building through the pursuit of a comprehensive strategy as one of the flagship projects under the financial sector. It is for this reason that the Presidential Circular No. 1 of 2008 on Organization of Government clearly pronounces the Diaspora Office as a major portfolio under the Ministry of Foreign Affairs. In view of this therefore, the Ministry of Foreign Affairs incorporated Diaspora Diplomacy as one of the key pillars in its Ministerial Strategic Plan and established a fully fledged Directorate to handle Diaspora Affairs. This is among the many Government strategies to harness the potential of the Kenyan Diaspora.

\section{Entrepreneurial Strategies for Growth of Business}

There are several strategies which entrepreneurs use in order to make progress in a market or a business adventure. The study focuses on the following three entreprneurial strategies.

Innovation. The conceptual relationship between entrepreneurship and innovation has been discussed in the literature for many years. The economics of innovation, in particular, have attracted increased attention in recent years (Arora, Fosfuri, \& Gambardella, 2002). Sundbo (1998) summarised the basic theories of the economics of innovation and identified three competing paradigms in the current theoretical discussion of innovation: the entrepreneur paradigm, the technology-economics paradigm, and the strategic paradigm. Innovation is the specific tool of entrepreneurship by which entrepreneurs exploit change as an opportunity for a different business or service. There is considerable overlap between entrepreneurship and innovation (Kanungo, 1999). Moreover, innovation has to address market needs, and requires entrepreneurship if it is to achieve commercial success (Zhao, 2001).

Networking. Alliances and networks can allow firms to acquire resources and capabilities that are difficult particularly important for new ventures, given the lack of resources they generally suffer from. Moreover, by leveraging external networks firms can access information, resources, markets, and technologies (Gulati, Nohria, \& Zaheer, 2000). Network-based research has provided interesting insights for entrepreneurship studies. The network perspective of entrepreneurship emphasizes that entrepreneurial activity is a relational and social task and that entrepreneurial process largely results in a networking activity. The very distinctive characteristic of the entrepreneur is to mobilize resources embedded in social relationships. Therefore, the process of resources accumulation can be explained over all in terms of the social interactions to which the nascent entrepreneur exposes himself (Alvarez \& Busenitz, 2001). Diverse networks and indirect ties create opportunities for boundary spanning and bridging ties and, as a consequence, for radical innovation. 
Successfully innovative organizations have strong communications across departmental lines between people with differing points of view (Koberg, Detienne, \& Heppard, 2003), and the same principle applies with regard to entrepreneurial learning. Diversity in learning is partially a function of the range of sectors through which entrepreneurs move. Diversity also depends on the number of "structural holes" in an entrepreneur's network. Structural holes exist when persons to whom entrepreneurs are linked are not themselves connected to one another (White, Boorman, \& Breiger, 1976). Ties can be bridges between sectors where a nascent entrepreneur currently has no direct ties (Burt, 2005).

Proactiveness. Proactiveness reflects an action-orientation. Kreiser, Marino, and Weave (2002, p. 79) define "proactiveness" as the "aggressive execution and follow-up actions to drive an enterprise toward the achievement of its objectives by whatever reasonable means required". As such, proactiveness has certain underlying attributes such as the enterprise's disposition towards its competitors, organisational pursuit of favourable business opportunities, its attitude to being a pioneer or fast follower, and a high regard for the initiative of employees (Knight, 1997, p. 213). Entrepreneurial enterprises have been conceptualised as showing "an aggressive competitive orientation". A characteristic of a proactive enterprise therefore involves aggressive and unconventional tactics towards rival enterprises in the same market segment (Knight, 1997, p. 215). Proactive enterprises constantly seek new opportunities by anticipating future demand and developing products and services in anticipation of customer needs (Kreiser et al., 2002). Furthermore, they also show initiative in the development of new procedures and technologies. Bateman and Crant (1993) developed the proactive personality concept, defining it as a relatively stable tendency to affect environmental change that differentiates people based on the extent to which they take action to influence their environments. Individuals with a prototypical proactive personality identify opportunities and act on them, show initiative, take action, and persevere until meaningful change occurs (Crant, 2000). In contrast, people who are not proactive exhibit the opposite patterns: they fail to identify, let alone seize opportunities to change things. Less proactive individuals are passive and reactive, preferring to adapt to circumstances rather than change them (Crant, 2000).

Strategic partnership. Collaboration across sectors can provide innovative solutions to social problems. Famous examples of solutions that were initiated by local social entrepreneurs are the Grameen Bank, one of the first initiatives towards micro-credit management and the Green Belt Movement, which aimed at mobilizing and supporting local ecological and economical development in East Africa (Alvord, Brown, \& Letts, 2004). Partnerships, i.e. the collaborations between combinations of public and/or private actors who start voluntarily to exchange resources and information, have become a way of fostering cross-sector social entrepreneurship (La Cour \& Andersen, 2007). In simple words, a strategic partnership is a "partnership" that offers businesses a chance to join forces for a mutually beneficial opportunity and sustained competitive advantage (Wei, 2007). There are four potential benefits that international business may realize from strategic partnerships.

Entrepreneurial growth. It is hard to imagine a small firm taking advantage of opportunity and having a considerable impact in the market without growing. According to Garnsey, Stam, and Heffernan (2006) the advantages of early growth are internal (learning effects) and well as external (market position). In this sense, the growth seems to come out as an important demonstration of the entrepreneurial behaviour of small firms (Green \& Brown, 1997). Firm's growth has become a very important topic in the field of strategic research. Davidsson (2002) discusses in what conditions the study of the growth contributes effectively to the understanding of the entrepreneurship process. According to these authors, to say that entrepreneurship is the 
same as creation of a new firm is to reduce the field of entrepreneurship, since it does not reflect, in a complete way, its contemporaneous definitions. Then he suggests that the researchers in this field should see the growth of a firm as part a complement of the entrepreneurship process.

\section{Research Methodology}

This study adopted an explanatory research design that enabled the researcher to analyze details in depth and generalize the findings of the larger population. The target population of this study was all the Kenyan diaspora entrepreneurs from whom a sample size of 121 diaspora entrepreneurs and four key informants from various diaspora offices was acquired. A questionnaire was the main instrument for collecting primary data whose output was complemented by an interview guide. The study used descriptive and inferential statistics in data analysis.

\section{Data Analysis and Findings}

\section{Innovations and Growth of Diaspora Entrepreneurship}

The survey revealed that most of the respondents agree that innovation strategy is a recipe for growth in diaspora entrepreneurship to a great extent as shown by mean $(>4.0)$ and standard deviation $(\sim 1)$. According to the respondents, growth in diaspora entrepreneurship can be achieved through: establishing new location of the business $(M=4.43)$, use of new suppliers $(M=4.22)$, use of new customers $(M=4.03)$, use of new technology in my business $(M=4.28)$, use of new varieties in the market $(M=4.33)$, use of trained new skills $(\mathrm{M}=4.22)$, use new pricing technique $(\mathrm{M}=4.21)$, and re-organising business personnel $(\mathrm{M}=3.91)$, as shown in Table 1.

Table 1

Innovativeness and Diaspora Entrepreneurship

\begin{tabular}{llllllll}
\hline Innovativeness & 1 & 2 & 3 & 4 & 5 & Mean & St. dv. \\
\hline Establishing new location of the business & 1.3 & 1.7 & 1.3 & 35.0 & 61.0 & 4.4346 & 1.18287 \\
Use of new suppliers & 2.6 & 3.0 & 3.6 & 47.2 & 44.2 & 4.2192 & 1.14044 \\
Use of new customers & 0 & 5.7 & 5.7 & 66.8 & 21.8 & 4.0392 & 1.27366 \\
Use of new technology in my business & 1.2 & 6.2 & 0 & 39.4 & 53.2 & 4.2807 & 1.21541 \\
Use of New varieties in the market & 1.3 & 1.8 & 0 & 41.1 & 55.8 & 4.3308 & 1.34548 \\
Use of trained new skills & 0 & 0 & 4.2 & 72.8 & 23.0 & 4.2223 & 1.00603 \\
Re-organised my business personnel & 2.6 & 3.4 & 32.6 & 54.2 & 7.2 & 3.9133 & 1.43651 \\
Use new pricing technique & 0 & 1.9 & 0 & 70.2 & 27.9 & 4.2113 & 1.12944 \\
\hline
\end{tabular}

Notes. NB. Assessed using five-point Likert scale where $5=$ very great extent, $4=$ great extent, $3=$ moderate extent, $2=$ less extent, and $1=$ no extent at all.

Kanungo (1999) observed that there is a considerable overlap between entrepreneurship and innovation. According to Jun and Deschoolmeester (2003) the entrepreneurs innovativeness is demonstrated by their willingness and capability to create a paradigm shift in science and technology and/or market structure in an industry from a macro perspective. From a micro perspective, the innovativeness is the willingness and the capability of entrepreneurs to influence the firms existing marketing resources, technological resources, skills, knowledge, capabilities, or strategy. This study found that innovation is integral to entrepreneurial growth in the diaspora entrepreneurship. 


\section{Networking and the Growth of Diaspora Entrepreneurship}

The survey results show that most of the respondents were in agreement that diaspora entrepreneurship growth can be achieved through proper networking strategies (mean $>4.0$ and standard deviation $\sim 1$ ). Further it shows that $92.1 \%$ agree that use of micro-credit institutions is highly important to growth, $94 \%$ support that linkages with diaspora organizations and offices are highly effective, $97.5 \%$ observed that to a great extent, creating social linkages with diaspora from other countries is important for entrepreneurial growth, $89.4 \%$ agreed that to a large extent, creating markets among host countries leads to entrepreneurial growth. Also according to $98.8 \%$ to a large extent, use of online links for advertisement is important to ensure entrepreneurial growth, and $98.3 \%$ agreed that to a great extent, linking with other Kenyan diaspora in host country is a recipe for entrepreneurial growth as shown in Table 2.

Table 2

Networking and Diaspora Entrepreneurship

\begin{tabular}{llllllll}
\hline Networking & 1 & 2 & 3 & 4 & 5 & Mean & St. dv. \\
\hline Use of micro credit institutions & 1.2 & 3.2 & 3.5 & 52.3 & 39.8 & 4.631 & 1.388 \\
Linking with diaspora organizations and offices & 2.5 & 1.5 & 2 & 42.8 & 51.2 & 4.731 & 1.431 \\
Creating social linkages with diaspora from other countries & 0 & 0 & 2.5 & 67.2 & 30.3 & 4.353 & 1.203 \\
Created market among host countries & 1.6 & 5.7 & 3.3 & 49.2 & 40.2 & 4.821 & 1.097 \\
Use of online links for advertisement & 0 & 1.2 & 0 & 66.7 & 32.1 & 4.236 & 1.066 \\
Linking with other Kenyan diaspora in host country & 2.5 & 3.9 & 4.4 & 56.2 & 33 & 4.275 & .703 \\
\hline
\end{tabular}

Notes. NB. Assessed using five-point Likert scale where $5=$ very great extent, $4=$ great extent, $3=$ moderate extent, $2=$ less extent, and $1=$ no extent at all.

Baum, Calabrese, and Silverman (2000) emphasized the impact of entrepreneur's networking behavior on new venture performance by highlighting that entrepreneurs with greater networking activity are more successful. Greve and Salaff (2003) were of the view that entrepreneurs may begin with identity-based networks comprising mainly strong ties to similar others, or with more instrumentally constructed networks that contain many weak ties to diverse others (Hite \& Hesterly, 2001). Sequeira and Rasheed (2006) found that ventures starting with networks centered around strong identity ties tend to reproduce already existing business models, while diverse ties (weak or strong) tend to promote innovation, an indication that through networking, innovation is realized. Entrepreneurs who have strong identity-based networks accumulate "cognitive capital" (Nahapiet \& Ghoshal, 1998), which provides them with a unique understanding of the needs and point of view of their communities. "Cognitive social capital" refers to a shared system of meanings that enables individuals within a network to make sense of the information they receive (De Carolis \& Saparito, 2006).

\section{Proactiveness and the Growth of Diaspora Entrepreneurship}

According to the study results, most of the respondents supported that proactiveness offers growth to diaspora entrepreneurs as shown by mean $(>4.0)$ and standard deviation $(\sim 1)$. This is further corroborated by findings which show that $94.5 \%$ of the employees agree that entrepreneurial growth can be achieved to a large extent by creation of new businesses, $94.5 \%$ believe it can be achieved to a great extent through creation of new markets, $95 \%$ agree that entrepreneurial growth is achievable through identification of new opportunities, $95.3 \%$ support that entrepreneurial growth is a result of doing market research within the host country, $96.4 \%$ of them agree that Diaspora entrepreneurship can grow through good timing of the business, and, $95.6 \%$ observes its growth as a result of strategic location of the business, as shown in Table 3. 
Table 3

Proactiveness and Diaspora Entrepreneurship

\begin{tabular}{llllllll}
\hline Proactiveness & 1 & 2 & 3 & 4 & 5 & Mean & St. dv. \\
\hline Created new businesses & 0 & 2.5 & 3 & 46.5 & 48 & 4.27 & 1.202 \\
Created new markets & 1.2 & 0 & 3.8 & 61.2 & 33.8 & 4.77 & 1.378 \\
Identified new opportunities in Host country & 3.8 & 0.9 & 0 & 55.6 & 39.7 & 4.27 & 1.241 \\
Doing market research of the host country population & 1.2 & 1.2 & 1.2 & 65.2 & 31.2 & 4.09 & 1.306 \\
Good timing of the business & 0 & 0 & 4.4 & 57 & 38.6 & 4.36 & 1.364 \\
Strategic location of the business & 1.2 & 5.6 & 1.2 & 65.8 & 26.2 & 4.52 & 1.078 \\
\hline
\end{tabular}

Notes. NB. Assessed using five-point Likert scale where $5=$ very great extent, $4=$ great extent, $3=$ moderate extent, $2=$ less extent, and $1=$ no extent at all.

Crant (2000) observed that individuals with a prototypical proactive personality identify opportunities and act on them, show initiative, take action, and persevere until meaningful change occurs, hence being able to manage in hardship environment in the business cycle making them some of the great entrepreneurs. Kim, Hon, and Crant (2009) found that proactive personality has been linked to a number of desirable personal and organizational outcomes, and their findings provided evidence that a proactive disposition has a link to the growth of entrepreneurial ventures. Therefore, the study found that Diaspora entrepreneurship growth is affected by proactiveness among the diaspora investors.

\section{Strategic Partnership and Diaspora Entrepreneurship}

The study found that generally, strategic partnership to a great extent has an impact on the growth of diaspora entrepreneurship with mean which was $>4.0$. Further analysis shows that, $97.2 \%$ agree that to a great extent, collaboration with Diaspora offices to gain support and create familiarity of business contributes to Diaspora entrepreneurial growth, $97.6 \%$ support that to a great extent, partnering with a large business to share risks contribute to diaspora entrepreneurship growth, $98.8 \%$ agree that partnership with an existing business of the host country provides a boost to growth of venture and entrepreneurship, and $92 \%$ agreed to a great extent to the view that partnership with a skilled person on the business provides a leeway for growth in Diaspora entrepreneurship.

Table 4

Strategic Partnership and Diaspora Entrepreneurship

\begin{tabular}{llllllll}
\hline Strategic partnership & 1 & 2 & 3 & 4 & 5 & Mean & St. dv. \\
\hline $\begin{array}{l}\text { Collaborated with Diaspora offices to gain support and } \\
\text { create familiarity of business }\end{array}$ & 1.1 & 0 & 1.7 & 66.5 & 30.7 & 4.35 & 1.146 \\
Partnered with a large business to share risks & 1.2 & 1.2 & 0 & 75.2 & 22.4 & 4.21 & 1.019 \\
Partnered with a host country existing business & 0 & 1.2 & 0 & 58.7 & 40.1 & 4.45 & 1.184 \\
Partnered with a skilled person on the business & 1.2 & 5.6 & 1.2 & 66.8 & 25.2 & 4.26 & 1.444 \\
\hline
\end{tabular}

Notes. NB. Assessed using five-point Likert scale where $5=$ very great extent, $4=$ great extent, $3=$ moderate extent, $2=$ less extent, and $1=$ no extent at all.

Wei (2007) observed that strategic partnership is a "partnership" that offers businesses a chance to join forces for a mutually beneficial opportunity and sustained competitive advantage, hence being an easy way of benefitting a firm to easily grow within a new market and faced by legal threats. La Cour and Andersen (2007) observed that partnerships, i.e. the collaborations between combinations of public and/or private actors who start voluntarily to exchange resources and information, have become a way of fostering cross-sector social 
entrepreneurship. The study found that strategic partnerships have an impact on the growth of Diaspora entrepreneurship among the Diaspora based Kenyans.

\section{Relationship Between Entrepreneurial Strategies and Growth of Diaspora Entrepreneurship}

Regression analysis was used to find out the relationship between entrepreneurship strategies on growth of Diaspora entrepreneurship and results are presented under this section. Table 5 presents the regression analysis outcome.

Table 5

Regression Analysis Output

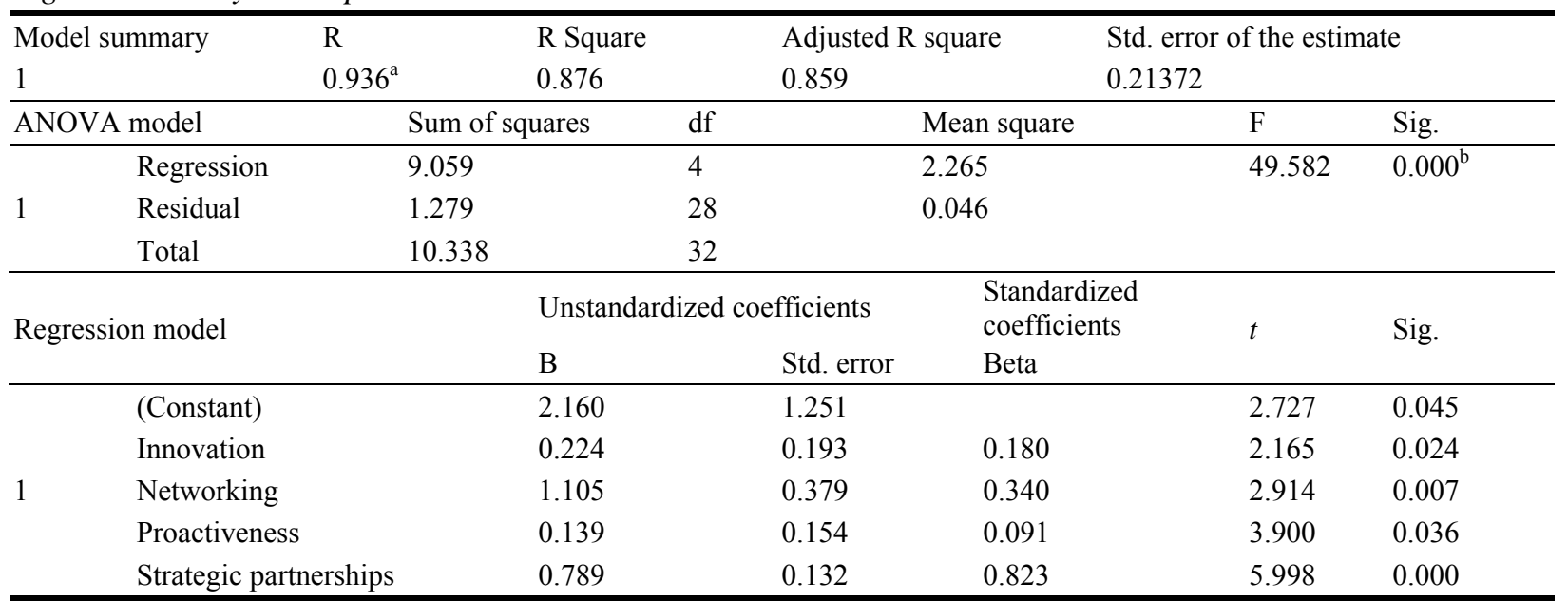

Notes. a. Predictors: (Constant), Innovation, Networking, Proactiveness, Strategic Partnerships; b. Dependent Variable:

Entrepreneurial Growth.

The study model adopted was follows:

$\mathrm{Y}=2.160+0.224 \mathrm{X}_{1}+1.105 \mathrm{X}_{2}+0.139 \mathrm{X}_{3}+0.789 \mathrm{X}_{4}+\varepsilon$

where: $\mathrm{Y}=$ Entrepreneurial Growth; $\mathrm{X}_{1}=$ Innovativeness; $\mathrm{X}_{2}=$ Networking; $\mathrm{X}_{3}=$ Proactivenesss; $\mathrm{X}_{4}=$ Strategic partnerships; $\varepsilon=$ Error term.

The adjusted $\mathrm{R}$ square value tells us that entrepreneurial strategies account for $87.6 \%$ of variance in the growth Diaspora entrepreneurship. These results are significant as explained by the F-ratio of 49.582 at a $p$-value $=0.000(\alpha=0.05)$. The study found positive regression coefficients for the Diaspora entrepreneurship strategies confirming that there is a positive effect on the entrepreneurial growth. According to Hair, Halle, Terry-Humen, Lavelle, and Calkins (2006) if the coefficient of the independent variables is really not all zero then the F-ration should be significantly greater than one and hence it can be stated that entrepreneurial strategies significantly influence Diaspora entrepreneurship growth and the level of its influences is significantly high 87.6\%. Study by Sakineh, Mehrdad, and Hasan (2012) which examined the relationship between entrepreneurial strategy and entrepreneurial growth supports the above findings. This research was conducted using descriptive-correlation approach and population of study involves the Kenyan Diaspora entrepreneurs. Pearson correlation test was used to determine the relationship between the elements of entrepreneurial strategies and Diaspora entrepreneurial growth at 5\% significant level and SPSS (version 20) statistical tool was used to analyze data. The result showed that entrepreneurial strategies such as innovation, networking, proactiveness, and strategic partnerships have significant relationship with diaspora entrepreneurial growth. 


\section{Conclusion}

The study found that Diaspora entrepreneurship growth can be achieved if the migrant entrepreneurs are able to adopt entrepreneurship strategies. The study found that entrepreneurship strategies such as innovation, networking, proactiveness, and strategic partnerships have an $87.6 \%$ impetus to improve entrepreneurial growth among the Kenyan Diaspora entrepreneurs. Therefore, the study concludes that Diaspora entrepreneurial strategies have the ability to enhance entrepreneurial growth among migrants.

\section{Recommendations}

The study recommends that Diaspora entrepreneurs should adopt Diaspora entreprenuership strategies that would enable them to grow their businesses and also to become more entrepreneurial. It is thus recommended that Kenyan embassies should provide entrepreneurial training so as to enhance the entrepreneurship knowledge among the Diaspora communities in host countries where they would be benefitted by getting involved in successful entrepreneurial undertakings.

\section{Suggestions for Further Research}

This study was undertaken among the Kenyan entrepreneurs based on Kenyan Diaspora and therefore the study suggests further research to be undertaken to further enhance these findings among other countries' Diaspora communities so as to provide further understanding on the topic.

\section{References}

Acs, Z. (2006). How is entrepreneurship good for economic growth? Innovations, 96-107.

Alvarez, S. A., \& Busenitz, L. W. (2001). The entrepreneurship of resource-based view. Journal of Management, 27, 755-775.

Alvord, S. H., Brown, L. D., \& Letts, C. W. (2004). Social entrepreneurship and societal transformation: An exploratory study. Journal of Applied Behavioral Science, 40, 260-282.

Ardichvili, A., Cardozo, R., \& Ray, S. (2003). A theory of entrepreneurial opportunity identification and development. Journal of Business Venturing, 18(1), 105-123.

Arora, A., Fosfuri, A., \& Gambardella, A. (2002). Markets for technology: The economics of innovation and corporate strategy. Cambridge, MA: MIT Press.

Arthur, S. J., Hisrich, R. D., \& Cabrera, Á. (2012). The importance of education in the entrepreneurial process: A world view. Journal of Small Business and Enterprise Development, 19(3), 500-514.

Baron, R. A. (2006). Opportunity recognition as pattern recognition: How entrepreneurs "connect the dots" to identify new business opportunities. Academy of Management Perspectives, 20(1), 104-119.

Bateman, T., \& Crant, J. (1993). The proactive component of organizational behavior: A measure and correlates. Journal of Organizational Behavior, 14(2), 103-118.

Baum, J. A. C., Calabrese, T., \& Silverman, B. S. (2000). Don't go it alone: Alliance network composition and startups' performance in Canadian biotechnology. Strategic Management Journal, 21(Special Issue), 267-294.

Benzing, C., Chu, H., \& Kara, O. (2009). Entrepreneurs in Turkey: A factor analysis of motivations, success factors, and problems. Journal of Small Business Management, 47(1), 58-91.

Burt, R. S. (2005). Brokerage and closure: An introduction to social capital. Oxford: Oxford University Press.

Chu, H. M., Benzing, C., \& McGee, C. (2007). Ghanaian and Kenyan entrepreneurs: A comparative analysis of their motivations, success characteristics and problems. Journal of Developmental Entrepreneurship, 12(03), 295-322.

Crant, J. (2000). Proactive behavior in organizations. Journal of Management, 26(3), 435-462.

Davidsson, P. (2002). Continued entrepreneurship and small firm growth. Stockholm: Stockholm School of Economics.

De Carolis, D. M., \& Saparito, P. (2006). Social capital, cognition, and entrepreneurial opportunities: A theoretical framework. Entrepreneurship Theory and Practice, 30(1), 41-56.

Eckhardt, J., \& Shane, S. (2003). The importance of opportunities to entrepreneurship. Journal of Management, 29(3), 333-349. 
Gaglio, C. M., \& Katz, J. A. (2001). The psychological basis of opportunity identification: Entrepreneurial alertness. Journal of Small Business Economics, 16, 95-111.

Garnsey, E., Stam, E., \& Heffernan, P. (2006). New firm growth: Exploring processes and paths. Industry and Innovation, 13(1), $1-20$.

Government of Kenya. (2008). Ministry of trade and industry. Nairobi: Government Press.

Green, R., \& Brown, S. (1997). Firm networks and firm development: The role of the relational mix. Journal of Business Venturing, 21(4), 514-540.

Greve, A., \& Salaff, J. W. (2003). Social networks and entrepreneurship. Entrepreneurship: Theory and Practice, $28(1), 1-22$.

Gulati, R., Nohria, N., \& Zaheer, A. (2000). Strategic networks. Strategic Management Journal, 21, 203-215.

Hair, E., Halle, T., Terry-Humen, E., Lavelle, B., \& Calkins, J. (2006). Children's school readiness in the ECLS-K: Predictions to academic, health, and social outcomes in first grade. Early Childhood Research Quarterly, 21(4), 431-454.

Hite, J. M., \& Hesterly, W. S. (2001). The evolution of firm networks: From emergence to early growth of the firm. Strategic Management Journal, 22(3), 275-286.

Holmes, T. J., \& Schmitz, J. A. J. (2001). A theory of entrepreneurship and its application to the study of business transfers. Journal Political Economics, 98, 265-294.

IMI Working Papers Series. (2011), No. 51 paths to viability transnational strategies among Ghana's small-scale ICT entrepreneurs (EN).

Jun, Z., \& Deschoolmeester, D. (2003). How to appraise entrepreneurs' innovativeness: Contextual framework. In Proceedings published by the 48th World Small Business Conference (ICSB), Belfast, UK.

Kanungo, R. N. (Ed.). (1999). Entrepreneurship and innovation: Models for development. London: Sage Publications.

Kim, T., Hon, A., \& Crant, J. (2009). Proactive personality, employee creativity, and newcomer outcomes: A longitudinal study. Journal of Business \& Psychology, 24(1), 93-103.

Kirzner, I. (1973). Competition \& entrepreneurship. Chicago: University of Chicago Press.

Knight, F. H. (1942). Profit and entrepreneurial functions. The Journal of Economic History, 2, 126-132.

Knight, G. A. (1997). Cross-cultural reliability and validity of a scale to measure firm entrepreneurial orientation. Journal of Business Venturing, 12(3), 213-225.

Koberg, C. S., Detienne, D. R., \& Heppard, K. A. (2003). An empirical test of environmental, organizational, and process factors affecting incremental and radical innovation. The Journal of High Technology Management Research, 14(1), 21-45.

Kreiser, P., Marino, L., \& Weaver, L. M. (2002). Assessing the relationship between entrepreneurial orientation, the external environment and firm performance. Frontiers of Entrepreneurship Research, Babson College. [Online] Available at: www.babson; edu/entrep/fer/Babson 202/XVII/XVII_S4/SVII_S4_hav.html

La Cour, A., \& Andersen, N. A. (2007). Fostering social entrepreneurship through partnerships. Copenhagen Business School, Copenhagen. Paper presented at Conference ISERCManev, I.M.

McGrath, R., Tsai, M., Venkataraman, S., \& MacMillan, I. (1996). Innovation, competitive advantage and rent: A model and test. Management Science, 42, 389-403.

Murphy, P. J., Liao, J., \& Welsch, H. P. (2006). A conceptual history of entrepreneurial thought. Journal of Management History, $12,12-35$.

Nahapiet, J., \& Ghoshal, S. (1998). Social capital, intellectual capital, and the organizational advantage. Academy of Management Review, 23(2), 242-266.

Newland, K., \& Tanaka, H. (2010). Mobilizing Diaspora entrepreneurship for development. Washington DC: Migration Policy Institute.

Njeru, G. R. (1996). Small-scale farmers as entrepreneurs: Some theoretical issues. Available at: www.unhabitat.org/downloads/docs/272turning_Job_Seekers_into_Job_Creators_in_Urban_India-Paper_Mahinda_edit.pdf

OECD. (2010). Open for business: Migrant entrepreneurship in OECD countries. OECD Publishing.

Portes, A. (Ed.) (1995). The economic sociology of immigration: Essays on networks, ethnicity, and entrepreneurship. New York: Russell Sage Foundation.

Portes, A., Guarnizo, L. E., \& Landolt, P. (1999). The study of transnationalism: pitfalls and promise of an emergent research field. Ethnic and Racial Studies, 22(2), 217-237.

Portes, A., \& Yiu, J. (2013). Entrepreneurship, transnationalism, and development. In: Migration studies. Oxford University Press.

Presidential Circular No. 1 of 2008 on Organization of Government. 
Sakineh, M., \& Hasan, A. (2012). Deconstructing the relationship between entrepreneurial orientation and business performance at the embryonic stage of firm growth. Industrial Marketing Management, 36(5), 651-661.

Schultz, T. W. (1979). Concepts of entrepreneurship and agricultural research. Kaldor Memorial Lecture, Iowa State University, October.

Sequeira, J. M., \& Rasheed, A. A. (2006). Start-up and growth of immigrant small businesses: The impact of social and human capital. Journal of Developmental Entrepreneurship, 11(04), 357-375.

Sundbo, J. (1998). The theory of innovation: Entrepreneurs, technology and strategy. Northampton, MA: Edward Elgar.

Vertovec, S. (2003). Migration and other modes of transnationalism: Towards conceptual cross-fertilization. International Migration Review, 37(3), 641-665.

Wei, Y. (2007) Factors influencing the success of virtual cooperation within Dutch-Chinese strategic alliances (Doctoral dissertation). University of Twente.

White, H. C., Boorman, S. A., \& Breiger, R. L. (1976). Social structure from multiple networks. I. blockmodels of roles and positions. The American Journal of Sociology, 81(4), 730-780.

Zhao, F. (2001). Managing innovation and quality of collaborative R\&D. Proceedings of 5th International \& 8th National Research Conference, Melbourne.

Zimmerman, M., \& Jiang, C. (2009). Social competence of women entrepreneurs: Moderating the effect of social-, human- and reputational capital on entrepreneurial success. Babson College Entrepreneurship Research Conference, Babson, Park, MA. 